\title{
Green procurement in South Africa: perspectives on legislative provisions in metropolitan municipalities
}

\author{
Adelaide Owusu Agyepong ${ }^{1}$ - Godwell Nhamo
}

Received: 24 May 2016/ Accepted: 23 September 2016/Published online: 7 October 2016

(C) The Author(s) 2016. This article is published with open access at Springerlink.com

\begin{abstract}
This paper sets an objective to analyse legislative provisions for green procurement in South Africa's metropolitan municipalities in the context of climate change and sustainable development. The main methods for data generation were interviews and document analysis. There were 30 interviews granted by among others, procurement officers, town planners and economic development specialists. In addition, 51 policy documents were retrieved, followed by a keyword search. The keywords were carefully selected and limited to those commonly used in green procurement terminology to include climate change, green procurement, renewable energy, energy efficiency, mitigation, clean technology, carbon footprint, sustainable development and green economy. The findings are that although all the metropolitan municipalities have procurement policies in place, only the City of Cape Town and eThekwini metropolitan have incorporated green procurement strategies into their supply chain management. The City of Cape Town and Nelson Mandela Bay metropolitan municipalities also emerged as the only ones with stand-alone green procurement strategies. To this end, the research concludes that legislative provisions mandating green procurement in South African metropolitan municipalities are not entirely lacking, although more work needs to be done to roll this out to cover all the existing metropolitan municipalities.
\end{abstract}

Keywords Green procurement - Metropolitan municipalities - Sustainable development · Climate change

\section{Introduction}

South Africa recognises the risk of general environmental decay and global warming, and is committed to responding to the climate change challenge (RSA 2009). To this end, the country has taken a number of steps to address this challenge through green policy

Adelaide Owusu Agyepong

agyepao@unisa.ac.za

1 University of South Africa (UNISA), P O Box 392, Pretoria 0003, South Africa 
formulation. Among the progressive green policies is the National Climate Change Response White Paper of 2011 (DEA 2011). One of the identified areas in which climate change can be addressed is through green (sustainable) public procurement, a concept suggested at the World Summit on Sustainable Development (WSSD 2002). Given that metropolitan municipalities are both centres of production and consumption, activities that significantly lead to greenhouse gases (GHG) emissions resulting in global warming and ultimately climate change, this study sought to analyse the extent to which green procurement is legislated in such. As a global player and ranked among the top 15 GHG emitters globally, it is inevitable that South Africa, and especially its local government, be seen to be doing something regarding GHG mitigation interventions through green procurement.

Matters of sustainable public procurement have been debated at length through the work of Helen Walker and colleagues and other authors (Walker and Brammer 2009; Brammer and Walker 2011; Crespin-Mazet and Dontenwill 2012; Testa et al. 2012; Correia et al. 2013; Touboulic and Walker 2015; Testa et al. 2016). Further details on the individual studies are presented in the literature section. However, what emerges from the reviewed literature is that limited work has been done to study green procurement in South Africa in general, and at metropolitan municipality level specifically. Local government (made up of metropolitan municipalities, local municipalities and District municipalities) is the third level of governance in the South African after the national and provincial administration (Republic of South Africa, RSA 1998). Metropolitan municipalities have more than 500,000 voters, and the metropolitan municipality coordinates the delivery of services to the whole area (Ibid). There are eight metropolitan municipalities in South Africa. These metropolitans are Buffalo City, City of Cape Town, City of Johannesburg, City of Tshwane, Ekurhuleni, eThekwini, Mangaung and Nelson Mandela Bay.

This paper comes in five major parts inclusive of the introduction and conclusion. The next section documents the methods used. This is followed by the literature featured in the third section. The fourth and critical part of the work analyses data and discusses findings before the conclusion in the fifth section.

\section{Materials and methods}

The paper sought to investigate and document legislative provisions for green procurement in metropolitan municipalities in South Africa. To this end, the objective set was to determine legislative provisions to enhance green procurement in South African metropolitan municipalities. The paper makes a contribution towards revealing the extent to which South African metropolitans have mainstreamed green procurement in their policies with the view to address climate change and sustainable development. The main method used to generate data for this paper was document analysis (Bailey 1994; Creswell 2003). Figure 1 shows all the eight metropolitans studied.

The retrieved and analysed documents included integrated development plans, supply chain management policies, environmental policies, integrated waste management policies, energy and climate change policies, green procurement guidelines and green procurement implementation strategies. A total of 51 such policy documents were retrieved, and a keyword search performed. The keywords were carefully selected and limited to those commonly used in green procurement. These keywords included: climate change, green procurement, renewable energy, energy efficiency, mitigation, adaptation, clean 


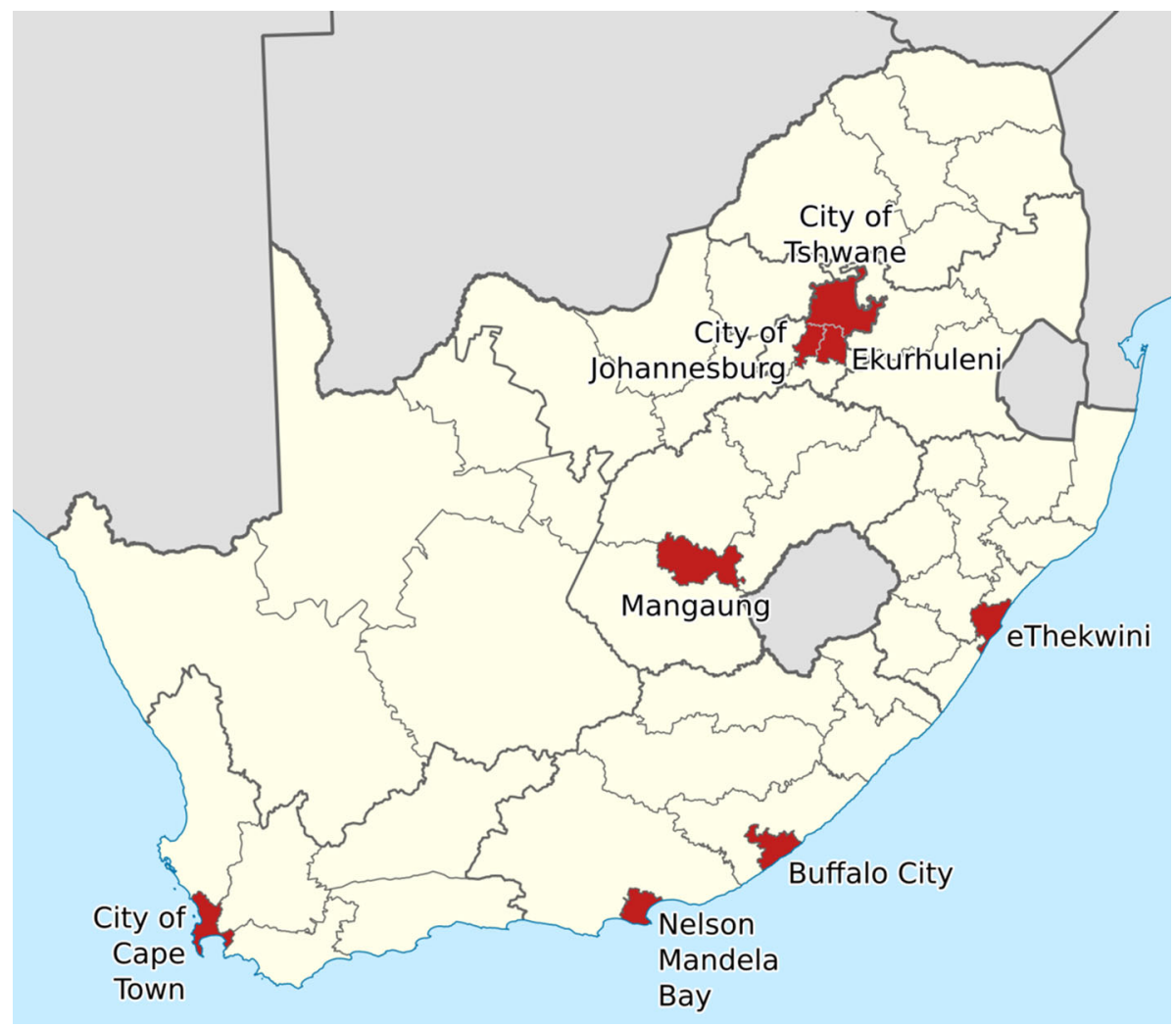

Fig. 1 Study sites. Source: https://www.google.com (Accessed 25 August 2016)

technology, carbon footprint, sustainable development and green economy. The documents were analysed to establish the link between the need for green procurement and any action being taken to address climate change in the metropolitan.

In addition to the policy analysis, narratives were collected through interviews with relevant officials. A total of 30 respondents granted interviews to answer the questionnaire from across six metropolitan municipalities that excluded Ekurhuleni and the City of Tshwane. Among those interviewed were five town planners, 11 procurement officers, 13 environmental specialists and one economic development specialist. The split in terms of the metropolitan was as follows: Buffalo City (4), City of Cape Town (5), City of Johannesburg (4), eThekwini (6), Mangaung (6) and Nelson Mandela Bay (5). City of Tshwane was excluded because it was used as a pilot in terms of refining the interview guide, while Ekurhuleni did not have willing representatives. However, all the metropolitan municipalities were included in the sample for document analysis.

Through the interviews, the respondents were requested to answer questions, among them those that triangulated the keyword searches. Additional concepts such as solar water heating $(\mathrm{SWH})$ were included. For example, question 40 in the questionnaire asked respondents to indicate on a Likert Scale, adequacy in understanding key concepts. Their responses would select among, 'Strongly Disagree', Disagree', 'Not Sure', 'Agree' and 'Strongly Agree'. Other questions probed staff training and capacity development in green procurement, barriers and opportunities to green procurement, etc. 


\section{The literature review: sustainability and green procurement}

The realisation that procurement impacts sustainability has given rise to the development of the sustainable procurement concept. The sustainable procurement concept is described by Walker and Brammer (2009: 128) as procurement that ensures 'a strong, healthy and just society, living within environmental limits and promoting good governance'. The United Kingdom Department of Environment, Food and Rural Affairs (DEFRA 2006) defines sustainable procurement as a process, whereby organisations meet their needs for goods, services, works and utilities in a way that achieves value for money on a whole-life basis in terms of generating benefits not only to the organisation, but also to society and the economy, while minimising damage to the environment (DEFRA 2006: 14). In addition to the definition of sustainable procurement, DEFRA (2006) posits that sustainable procurement "should consider the environmental, social and economic consequences of: design, non-renewable material use, manufacture and production methods, logistics, service delivery, operation, maintenance, reuse, recycling options, disposal and suppliers' capabilities to address these consequences throughout the supply chain' (Ibid: 10). Sustainable procurement just like procurement can be conducted both in the private and public sector spheres and local government; particularly, metropolitan municipalities are big players in this equation.

Linked to sustainable procurement is the concept of green procurement. Green procurement refers to basing all purchasing decisions and allocation of contracts on environmental criteria along with other criteria such as quality, price and delivery (International Council for Local Environmental Initiatives-ICLEI 2000). As highlighted earlier, the desire to address climate change is central to procuring green. Stigson and Russell (1998) indicate that procuring green should include a process of ensuring that suppliers meet required environmental standards. ICLEI (2000) is of the opinion that apart from green procurement positively contributing to environmental protection at a local level; it also creates a powerful market demand for greening production. This way, green procurement serves as a model to influence the behaviour of companies, private institutions and households. In the public sector, green procurement will thus influence any procurement action that is aimed at reducing greenhouse gas (GHG) emissions that result in global warming leading to address climate change. For the purpose of this study, green procurement is considered to be the purchasing of goods and services that reduce negative impacts on the environment, with a special emphasis on the desire to address climate change. While the discourses surrounding sustainable development, sustainable procurement and green procurement continue, a notable challenge globally as indicated earlier is climate change. Climate change comes about mainly as a result of GHG emissions generated by various human-induced activities (Klein et al. 2005). There are two main approaches of dealing with climate change, and these are mitigation and adaptation (Harrison et al. 2010; UNDESA 2013). The nexus between climate change mitigation, adaptation and green procurement is the focus of the next paragraphs.

Mitigation addresses the climate change challenge through seeking a reduction or elimination of anthropogenic generated greenhouse gas emissions into the atmosphere. Adaptation on the other hand addresses climate change through reducing the adverse impacts of climate change as well as exploiting economic and social opportunities presented by climate change. Green procurement has been identified as one of the climate change intervention measures. This is because research shows that procurement policies and practices of both the public and private sectors have the potential to influence 
environmentally friendly modes of production and the provision of 'greener' goods and services that include infrastructure. In many developing countries, the big spending power of the public sector, particularly municipalities, makes them influential players in the nature of goods and services production and provision.

A number of countries are striving to combat climate change by implementing either mitigation or adaptation strategies. Green procurement forms an integral part of these strategies. Some of the advanced and visible green procurement practices are in place in the Organisation of Economic Co-operation and Development countries (OECD). One of the objectives of the OECD is to address the sustainability challenges of globalisation that include economic, social and environmental challenges (OECD 2007). Drawing from the World Summit on Sustainable Development (WSSD), the OECD council recommended the incorporation of environmental concerns in the public procurement practices and policies of its member states (Ibid). In a demonstration of commitment to this focus, the OECD established an environmental policy committee (EPC) in 2002. The committee came up with green procurement recommendations pertaining to the products and services for public procurement consideration for all member states. The objective was and still is to improve environmental performance of public procurement, and to promote continuous improvement in the environmental performance of products and services. Secondly, the committee recommended that member states develop green procurement policies to be consistent with their other relevant existing national policies. Member states were mandated to also take the necessary steps to incorporate environmental criteria into their public procurement of products and services. Thirdly, the EPC was to support member countries to develop and apply efficient and effective green public purchasing policies by collecting and disseminating information on 'best practices' to all member states.

From the UK, Walker and Brammer (2009) established that green procurement at local government level emphasised strongly on purchasing from local and small suppliers with cost being the leading barrier to achieving sustainable procurement. In a similar follow-up study (Brammer and Walker 2011), the authors looked at 20 countries and determined that policies and practices in sustainable procurement differed greatly across regions. In South Africa, it emerged that public procurement was viewed as a policy lever to redress the injustices of apartheid with government deliberately preferring to buy from black-owned businesses that would otherwise not comply with green credentials (Ibid). Crespin-Mazet and Dontenwill (2012) present a gardening firm case study in which the company went the route of sustainable procurement in order to meet the demands of sustainable development. In a similar study, Touboulic and Walker (2015) looked at sustainable supply chain management across the UK private sector, while Testa et al. (2016) analysed 164 Italian public tenders in the building and construction sector based on the European Commission green public procurement toolkit. The results from Testa el al. (Ibid) showed limited use of green criteria in the tender documents. Correia et al. (2013), bring up the notion of low carbon procurement as an emerging policy agenda in the UK, which is driven by the desire to reduce GHG emissions, thereby linking directly into sustainable procurement.

The rules and regulation governing procurement within South Africa's organs of state are outline in section 217 of is the Constitution of South Africa (RSA 1996). Section 24 of the Constitution states that: everyone has the right to an environment that is not harmful to their health or well-being. Drawing from the Constitution, the Public Finance Management Act (PFMA) was enacted in 1999. The PFMA is the framework governing procurement practices of national and provincial governments. The aim of the PFMA (RSA 1999) is to achieve good financial management, to maximise service delivery through effective and efficient use of limited resources (RSA 1999). After the PFMA, the Preferential 
Procurement Policy Framework, PPPFA (Act 5 of 2000), was enacted in 2000. The Act guides procurement within organs of state by providing a framework to give effect to Section 217(2) of the constitution. Section 2 (1) of this Act state that all organs of state must have a preferential procurement policy and the implementation of the policy among others must include: 'contracting with persons, or categories of persons, historically disadvantaged by unfair discrimination on the basis of race, gender or disability' (RSA 2000).

Although the PFMA (RSA 1999) and the PPPFA (RSA 2000) are both the overarching framework for procurement in national and provincial governments, the Acts do not make provision for the inclusion of environmental considerations in procurement (Bolton 2008:1). However, metropolitan municipalities in South Africa have started grappling with the notion of green procurement, mainly emerging from their environmental policies. The next paragraphs focus on a review of selected case studies in green procurement in the cities of Toronto, Rio de Janeiro and Mexico City.

In line with the Canadian National Government's 2006 Green Procurement Policy (GPP), the City of Toronto undertook a number of projects. The methane capture project addresses the city's drive of generating and supplying cleaner electricity. As the largest city in Canada, Toronto has a high demand for electricity to serve its slightly over three million residents (City of Toronto 2012). The city embarked on a project to capture methane gas from its main landfill site. The landfill is in an urban centre close to a residential area. In order to dispose of the odour and methane gas that was being emitted from the landfill, the landfill gas (LFG) was captured, redirected and converted to energy that was able to provide power for 24,000 households. An annual profit of 3-4 million Canadian dollars per annum (2012) was realised through this project. According to the city, the landfill reached its maximum and closed down in 2002. However, LFG is still being harvested and will continue until the methane gas is depleted (Ibid). The setting up of the facility to capture LFG needed the expertise of service providers with an understanding of several concepts around climate change mitigation. In awarding a contract to set up the LFG facility, green procurement was practiced.

Another methane capture project is the Gramacho landfill gas to energy project in Rio de Janeiro. The Gramacho landfill site receives an average of 3 million tonnes of waste annually. A methane capturing system was installed to capture about 119 million $\mathrm{Nm}^{3}$ of methane gas produced (Rio de Janeiro 2012). Energy produced through this project is sold back to an energy facility thereby generating an income to be used by the facility. Projected benefits of the programme include the overall reduction of 5.96 tonnes of carbon dioxide emissions and the production of 90 million Nm3 biogas over a 20-year period (Ibid). Lessons from these projects are critical as one analysis whether similar sustainability and green procurement projects are being implemented in South African metropolitan municipalities. Hence, during the presentation of data, analysis and discussion of research findings, cross reference will be made to such instances to confirm decline or come up with new findings.

Fuel-efficient taxi (FET) system will be discussed for Mexico City. In a bid to reduce motor vehicle emissions, Mexico City implemented FET programme also known as the Government of Mexico City's Taxi Substitution Program. The programme was sponsored by the Mexico City municipality (Mexico City 2011). The project sought to reduce carbon emissions by replacing 10,000 of Mexico City's older taxis with new and fuel-efficient models by the year 2012. Under the programme, the metropolitan municipality subsidised the purchasing of new taxis meeting a number of stringent specification most notably and of relevance to the environment, a fuel economy of $12.5 \mathrm{~km}$ per litre of fuel (Ibid). The metropolitan subsidy was one-fifth of the total price of a new fuel-efficient taxi to taxi 
drivers to purchasing new vehicles. The balance of the purchasing price was financed with loans from a local bank and was payable over a period of 4 years. This case clearly illustrates a green procurement initiative with a municipality interacting with its citizens in ensuring that the citizens' economic and social needs are met and environmental degradation is curtailed.

The literature emerging on sustainable (including green) procurement falls into four broad categories namely: (1) that which address the national government needs, (2) state and/or provincial government requirements, (3) local government issues and (4) that coming at the corporate and/or company level. Of interest to note is how the responsible governments from the national, through state and/or provincial, to local level, take deliberate decisions to institute appropriate legislation to govern and direct such green procurement practices. Capacity development and training also came out as necessities for green procurement. The legislation spoken about includes preferential treatment of smalland medium-scale enterprises as well as local suppliers that shorten the supply chains. Finally, the high awareness levels regarding the negative impacts of global warming due to the emission of harmful GHGs resulting in climate change compel stakeholders to do something from a procurement angle. Emitted GHGs result in huge carbon footprints that are not desirable from both the regulatory and reputational risk of governments at whatever sphere and companies too. Such risks drive many public and private stakeholders into sustainable procurement practices. However, for our generation, green procurement should kick in as an ethics issue as it is the right thing to do. The world has witnessed the negative impacts of extreme weather events from the changing climate such as droughts, floods, extreme frost, heat waves and wild fires that threaten to reverse the gains of the past three or so decades in eradicating poverty. The next section presents and discusses the findings from the current study.

\section{Results and discussions}

\subsection{Green procurement in policies and understanding of concepts}

To assess the level of commitment to green procurement as a mitigation strategy to addressing climate change within South African metropolitan municipalities, the research analysed a number of policy documents guiding both the development visions and related practices of the metropolitan municipalities. As indicated in the Sect 2, the analysis started from simple frequency counts of key green procurement terminologies in the 51 reviewed policy documents. The analysed policy documents (Table 1) indicate a general awareness of green procurement (inclusive of climate change discourses) in the metropolitan municipalities.

There were a total of 2237 cases of reference to the stated key terminology associated with green procurement in the reviewed documents. Within this count, the term green procurement feature 393 times constituting a significant $18 \%$ of the total frequency. Although green procurement is a climate change mitigation strategy, the term 'mitigation' is mentioned at a frequency of only $4 \%$. This revelation suggests that the linkages between climate change mitigation and green procurement still need to be strengthened in the metropolitan municipalities informing this study. Having established the frequency of the identified terms in the documents, respondents were asked to indicate their level understanding of the terms through a questionnaire. The questionnaire classified the 
Table 1 Reference to key green procurement terminology $(n=51)$

Source Fieldwork (2013)

\begin{tabular}{lcl}
\hline Theme & Frequency & Percentage (\%) \\
\hline Climate change & 710 & 32 \\
Green procurement & 393 & 18 \\
Renewable energy & 189 & 8 \\
Energy efficiency & 297 & 13 \\
Mitigation & 84 & 4 \\
Adaptation & 225 & 10 \\
Clean technology & 2 & - \\
Carbon footprint & 22 & 1 \\
Sustainable development & 283 & 13 \\
Green economy & 32 & 1 \\
Total & 2237 & 100 \\
\hline
\end{tabular}

understanding of the terms under five categories in which the respondents either 'Strongly Disagreed', 'Disagreed', 'Not Sure', 'Agreed' or 'Strongly Agreed' that they understood the meaning of each of these terms. Table 2 gives the results of the findings of this part of the inquiry.

From Table 2, it emerges that there is good understanding of the key concepts associated with green procurement among metropolitan respondents. Further to understanding key concepts related to green procurement, legislating green procurement was reiterated by several of the respondents. One respondent stated that: 'If government does not legislate green procurement, it will never be implemented as people's mindsets and perspectives can only be changed through legislation' (Excerpt from interview, Buffalo City 2013). There are moves to try and legislate green procurement practices at local government level. For example, a respondent from the Nelson Mandela Bay indicated that although the metropolitan had developed a strategy for green procurement, council was yet to accept

Table 2 Understanding of concepts related to green procurement $(n=30)$

\begin{tabular}{lllllll}
\hline Concept & $\begin{array}{l}\text { Strongly disagree } \\
(\%)\end{array}$ & $\begin{array}{l}\text { Disagree } \\
(\%)\end{array}$ & $\begin{array}{l}\text { Not sure } \\
(\%)\end{array}$ & $\begin{array}{l}\text { Agree } \\
(\%)\end{array}$ & $\begin{array}{l}\text { Strongly agree } \\
(\%)\end{array}$ & $\begin{array}{l}\text { Total } \\
(\%)\end{array}$ \\
\hline Renewable energy & 4 & - & 4 & 67 & 25 & 100 \\
Energy efficiency & 4 & - & 4 & 58 & 34 & 100 \\
Climate change & 4 & 4 & 4 & 53 & 35 & 100 \\
Green procurement & 4 & 4 & 16 & 64 & 12 & 100 \\
Mitigation & 4 & - & 15 & 54 & 27 & 100 \\
Adaption & 4 & - & 16 & 52 & 28 & 100 \\
Clean technology & 4 & - & 40 & 40 & 16 & 100 \\
Carbon footprint & 4 & 8 & 15 & 50 & 23 & 100 \\
Sustainable & 4 & - & 15 & 46 & 35 & 100 \\
$\quad$ development & & 4 & & & & 100 \\
Green economy & 4 & - & 8 & 60 & 28 & \\
Solar water heating & 4 & & & & & 100 \\
\hline
\end{tabular}

Source Fieldwork (2013) 
and adopt the proposed strategy. The respondent indicated that because the green procurement strategy is just a strategic way to implement green procurement practices, it is not being taken very seriously. The respondent suggested a need to address green procurement through legislation beginning with national legislation by stating that:

The PPFMA should be amended by inserting a paragraph for green procurement... it will then become legislatively enforceable for procurement officials to implement it. The Legislation will be a driver for demand [of green products and services] (Excerpt from interview, Nelson Mandela Bay 2013).

A respondent from Buffalo City reiterated that the point system as outlined in the PPPFA regulation for awarding tenders should be restructured to include green procurement. The respondent said that instead of the $80 / 20$ and the $90 / 10$ points in which 80 and 90 points are allocated to price, it should be restructured as $70 / 20 / 10$ or $80 / 10 / 10$ with the ten points allocated to environmental consideration. Noting that Table 1 shows an aggregated reference to all reviewed document, the research sought to disaggregate this reference to specific document in order to address the research objectives.

Given that not all policy documents significantly impact on green procurement in general, and green procurement in the metropolitan municipalities, specifically, only key policy documents were selected for further analysis. Among such key policy documents were: the integrated development plans, the environmental policies and the supply chain management policies.

\subsection{Integrated development plans (IDPs)}

The IDP is the overarching strategic framework for the development of a metropolitan. As such all the metropolitan municipalities must have IDPs. The IDPs of the metropolitans were analysed to determine two issues. The first was to establish if any of the documents made mention of the identified themes in their development strategy. Secondly, the analysis sought to determine if there was a strategic move to address climate change through green procurement (Table 3).

From the IDPs retrieved, only one metropolitan IDP made an explicit reference to green procurement. The other IDPs used related terms without the use of the term 'green procurement'. The Brundtland Commission (World Commission on Environment and Development-WCED 1987) states that 'the environment is where we live; and development is what we all do in attempting to improve our lot within that abode, therefore the two are inseparable' (WCED 1987: 8). This assertion is an indication of the need to consciously and deliberately formulate and legislate environmental management as an integral part of economic development. Against this background, the research sought to determine the available and adequacy of the environmental policies in the metropolitans covered by this research.

\subsection{Environmental policy}

It was observed that all the older metropolitans namely; City of Cape Town, City of Johannesburg, City of Tshwane, Ekurhuleni, eThekwini and Nelson Mandela Bay have environmental policies in place. A list of these policies is given in Table 4. This was in contrast to the younger metropolitans such as Buffalo City and Mangaung that have environmental statements but are yet to develop the statement into fully fledged environmental policies. 
Table 3 Reference to green procurement related terms in IDPs

Source Fieldwork (2013)

\begin{tabular}{lll}
\hline Theme & Frequency & Percentage (\%) \\
\hline Climate change & 154 & 36 \\
Green procurement & 2 & 0.4 \\
Renewable energy & 43 & 10 \\
Energy efficiency & 34 & 8 \\
Mitigation & 46 & 11 \\
Adaptation & 41 & 9 \\
Clean technology & - & - \\
Carbon footprint & 5 & 1 \\
Sustainable development & 87 & 20 \\
Green economy & 21 & 5 \\
Total & 433 & 100 \\
\hline
\end{tabular}

Table 4 Summary of environmental policies in the metropolitans

\begin{tabular}{llr}
\hline Metropolitan & Name of environmental policy & Year \\
\hline City of Cape Town & Integrated metropolitan environmental policy & 2003 \\
City of Johannesburg & Environmental management framework & 2000 \\
City of Tshwane & Tshwane integrated environmental policy & 2005 \\
Ekurhuleni & Environmental policy & 2006 \\
Ekurhuleni & Environmental policy and implementation plan & 2013 \\
eThekwini & Environmental policy (construction) & 2002 \\
eThekwini & Environmental management policy & 2005 \\
Nelson Mandela Bay & Integrated environmental policy & 2012 \\
\hline
\end{tabular}

Source Fieldwork (2013)

These environmental policies of the metropolitan were analysed for any mention of green procurement. The study found out that three of the metropolitans made reference to green procurement in their environmental policy. These are the City of Tshwane in its 2005 Integrated Environmental Policy (TIEP), Ekurhuleni in its 2013 Environmental Policy and Nelson Mandela Bay in its Integrated Environmental Policy (2012). The environmental policies of these three metropolitans in addition to City of Cape Town will further be interrogated in subsequent paragraphs to highlight green procurement projects that are mentioned in the policies.

\subsubsection{City of Tshwane}

Of the three metropolitans that make reference to green procurement in their environmental policies, the TIEP was found to be the most comprehensive in terms of green procurement. Section 5.4.6 of the TIEP supports the green procurement concept by indicating the promotion and implementation of green procurement practices (City of Tshwane 2005). To support this objective, a green procurement guideline was to be developed. The guideline was proposed to select five categories of products that are environmentally friendly annually, and these were to be included in the city's procurement list (City of Tshwane 2007). As at the time of the study (2013), the proposed guideline had not been developed. 
The TIEP also has a section dedicated to the green buildings cause. A green building is a building that incorporates environmental considerations into the infrastructure construction and maintenance (City of Tshwane 2005). Section 5.4.2 of the TIEP encourages the implementation of green building initiatives (Ibid). In view of that, both green building guidelines and green building guidelines for low-cost housing were to be developed to specify practices that will incorporate sustainable technologies in all building works (Ibid). The policy further suggested the need for the building industry supply chain to consider environmental issues in its practices. The policy proposed incentives to encourage the desired practices (City of Tshwane 2007). In response to the green buildings initiative as specified in the TIEP, the City of Tshwane through its Agriculture and Environmental management Department in collaboration with Council for Scientific and Industrial Research (CSIR South Africa) developed three instruments to ensure a sustainable built environment. These are: (1) Green Building Development By-law (2013) which outlines the legislative status for both the Green Building Development Policy and the Green Building Development incentive scheme, (2) Green Building Development Policy (2009) which indicates either mandatory or promoted guidelines for the development of green buildings and (3) Green building Development Incentive Scheme which encourages the adoption of promoted standards instead of mandatory standard for new buildings (Ibid).

\subsubsection{Ekurhuleni}

Ekurhuleni is one of the three metropolitan municipalities situated in the Gauteng Province. The metropolitan is heavily industrialised with South Africa's largest airport; the OR Tambo International Airport located within the metropolis (Ekurhuleni 2013). The use of coal and wood for domestic use especially in low-income households contributes to pollution and is also a health risk. The Ekurhuleni (2013) Environmental Policy and implementation plan was revised from its (2006) policy and therefore builds on the momentum of the metropolitan's energy policy to support reduction in pollution and the use of renewable energy (Ibid). In view of this, Ekurhuleni commissioned South Africa's first solar PV plant in 2012 (Ekurhuleni 2012). The energy that is generated by the PV plant is converted by an inverter and fed directly into the municipal grid from which electricity is supplied to 133 low-cost housing (ibid).

\subsubsection{Nelson Mandela bay}

Section 6 of the NMBM 2012 Integrated Environmental Policy highlights the metropolitan's commitments towards identified sectors. Section 6.8 recommends a sustainable transport system with less impact on the environment. In line with other metropolitan municipalities under study, the NMBM implemented the BRT system to reduce the carbon footprint of the metropolitan, among other reasons. The NMBM BRT was branded 'Libhongolethu', which means 'our pride' (Adewumi and Allophi 2014). Unlike other BRT's in other cities, the Libhongoletu which started operating in 2010 to meet the then World cup demands had to be put on hold due to challenges that included badly constructed roads. Libhongoletu was later restructured and commenced services again in 2013 (Ibid). The NMBM BRT faces other challenges that make it not conformable to standard BRT system. The challenges include the following:

1. Buses operate in a mixed traffic flow with no dedicated bus lanes.

2. No specially constructed BRT stations. 
3. Buses are not linked to a central control point for schedule updates on bus routes and.

4. Fares are collected in the bus.

The outlined challenges of the Libhongolethu should be addressed to make it more viable and attractive to commuters. This will bring the system at par with its counterparts in other cities within South Africa.

\subsubsection{City of Cape Town}

Although the City of Cape Town's IMEP does not make reference to green procurement, the IMEP outlines a number of strategies to be implemented to ensure the overall sustainability of the metropolitan (City of Cape Town 2003). Section 2 of the IMEP outlines the City's 2020 vision for the environment. As part of the vision, the IMEP suggests the implementation of a public transport system that would reduce pollution and congestion on the city's roads (Ibid). Section 4.9 of the IMEP is on energy. Under this section, the city recognises the dual role of energy; its importance in development and its negative effect on the environment (City of Cape Town 2003). In view of this, IMEP supports and promotes the use of 'alternative, renewable, cleaner and safer energy sources' (Ibid, 11). To give effect to this section of the IMEP, the City of Cape Town in a media release on 27th February (2006) claimed the leading role of the city in the use of solar energy. It was stated in the media release that solar water heating systems was to be installed in low-cost housing, resulting in a savings of about 50,000 tons of carbon emissions per annum (City of Cape Town 2006).

Besides analysing documents for reference to green procurement, the research also engaged the staff in these metropolitan municipalities seeking to determine the level of awareness on the presence or lack of knowledge about the existence of environmental policies. The inquiry revealed that $77 \%$ of the respondents $(n=30)$ were aware of the existence of environmental policies and practices in their metropolitans, $8 \%$ indicated that their metro had no policy and $15 \%$ indicated that they did not know if their metro had a policy or not. Inspired by the adage 'the taste of the pudding is in the eating', the research further sought to explore supply chain management policies of the metropolitan municipalities under study focusing on existing green procurement strategies.

\subsection{Supply chain management (SCM) policy}

It is mandatory for all metropolitans to have supply chain management (SCM) policies. The SCM are governed by regulation specified in the Municipal Finance Management Act 56 of 2003 (MFMA). The analysis revealed that two metropolitans, the City of Cape Town and eThekwini metropolitans, make reference to green procurement in their amended SCM policies; the City of Cape Town supply chain management policy (incorporating preferential procurement-2013) and the eThekwini supply chain management policy (2013). All respondents from these two metropolitans indicated awareness of the existence of these policies. Cape Town's SCM policy states that green procurement practices should be an integral part of procuring goods, services and construction works used in the metropolitan. The inclusion of green procurement into the policy therefore gave impetus to the development of city's green procurement guideline document. The eThekwini SCM (2013) on the other hand has a whole section dedicated to green procurement. Section (54) of the SCM is on green procurement. Green procurement in the metropolitan aims to: 
1. Encourage a decrease in energy and resource use.

2. Promote environmental best practices in terms of waste minimisation and management, water and energy efficiency and conservation, pollution reduction and socioeconomic development and.

3. Encourage suppliers to change their behaviour for environmental issues in the design, manufacture and disposal of their products (eThekwini 2013 :69).

The section encourages the development of a green procurement policy in consultation with stakeholders. The stakeholders will be trained to understand environmental specifications that will be developed and used in tender processes. Finally, a questionnaire will be used to determine the environmental commitment of suppliers. This strategy is however yet to be implemented as at the time of the study. The study further revealed that the Nelson Mandela Bay Metropolitan (NMBM) and City of Cape Town (CoCT) had developed green procurement strategies: the NMBM Implementation strategy on green procurement (2011) and the CoCT Information and Guideline Document on the implementation of Green Public Procurement (2012). The subsequent subsections will discuss further details regarding the existing green procurement guidelines and strategies.

\subsection{Existing green procurement guidelines and strategies}

Two metropolitans that have made significant strides towards green procurement are City of Cape Town and Nelson Mandela Bay. The City of Cape Town recognised the need for green procurement as far back as 2006 in the city's Integrated Waste Management Policy (IWMP). However, it was not until 2012 that the city developed guidelines documenting the implementation of green public procurement. The guideline document was developed as an annexure to the city's 2006 SCM policy. The main aim of the guideline document is to reduce the direct and indirect negative impact of SCM decisions on the environment (City of Cape Town 2012). The guideline document gives pointers on the relationship between green procurement and the SCM policy under two main sections. These are the acquisition management section which includes bid specification committees and the disposal and risk management sections. Under the acquisition management section, the document encourages green procurement to be included in all the stages of procurement. Under the bid specification committees, a number of generic selection criteria are outlined to be considered when tenders are evaluated. Among the generic selection criteria are the minimisation of waste, energy consumption, emissions and the use of hazardous substances in manufacturing (Ibid). The generic selection also encourages the use of environmentally certified suppliers (ibid 6). Included in the disposal and risk management section is the promotion of incentives for suppliers who engages in environmentally friendly disposal of goods. The guideline document suggests that the implementation of green procurement should take place in phases depending on the capacity and resources available. For the implementation to be successful, the city is mandated to identify products and services that are considered to be green to be included in specifications for tenders. Despite the development of the guidelines, the study found that there is still limited recognition of green procurement in the metros. The responding Cape Town procurement officials insisted on not being responsible for greening specifications and that they only comply with specifications received from various departments. This assertion corroborates the finding of Turley and Perera (2014) and implies that although green procurement strategy has been acknowledged at a strategic level, the implementation of it is still lacking. 
The Nelson Mandela Bay green procurement implementation strategy is a recommended strategy that was developed in 2011 and approved by council in 2014 (Personal communications with NMBM respondent 2014). The aim of the strategy is to incorporate environmental aspects into all the metropolitan's procurement activities (NMBM 2011). Two policies in the metropolitan were reviewed to identify areas where green procurement will be applicable. The two policies are the NMBM Integrated Environmental Policy (2012) and the NMBM SCM Policy (2013). The implementation strategy proposed amendments to both policies to include environmental considerations (Ibid). Amendments to the environmental policy are:

1. The term green procurement was added to the glossary section as: 'green' (sustainable) procurement which is defined as 'systematically integrating environmental and social considerations into all procurement activities. It is a system or procedure where environmental considerations are taken into account within the procurement process' (Ibid: 35).

2. An additional paragraph was added stating that: 'the NMBM aims to reduce any harmful effects on the environment caused by its activities, products and services through the adoption of environmentally sound procurement policies and practices' (Ibid: 35).

3. An additional principle was added articulating the needs for the implementation of green procurement practices into the supply chain management and to promote environmental responsibility and performance of suppliers' (Ibid: 35).

Four main additions were recommended to be included in the SCM policy. The additions were in sections 11, 14, 27 and the Annexure 'A' of the policy. Section 11 deals with system of acquisition management. The addition to this section is to incorporate environmental considerations 'in the acquisition process and to form a component of the bid specification' (Ibid: 36). Under section 14, issues of a list of accredited providers are addressed. The policy specifies that accredited service providers should be listed and the addition to this Section is for the inclusion of the environmental performance of accredited service providers (Ibid). Another addition states that:

Environmental considerations are to be given equal weighting along with other aspects when selecting preferred suppliers and goods. While paying due regard to price and quality, the specifications must encourage the purchasing of goods and services that will have the least possible impact on the environment during their life cycles (Ibid: 36 ).

Besides amending the environmental policy and the SCM policy, the green procurement strategy also uses the supplier focus approach to drive the green procurement practice. Through the use of questionnaires, audits and rating systems, suppliers are rated on their environmental performance and awarded a 'Green Certificate'. The Green Certificate qualifies a supplier for inclusion in the list of approved suppliers and is an important component of tender documents. The metropolitan intends to implement the strategy in 3 years and in seven phases. Phase one will be to educate Council through workshops, phase two will seek to build capacity within the metropolitan, phase three will focus on education and increasing awareness among the public, phase four will focus on the development of registration system, phase five the registration of companies into the metropolitan database, phase six the training of a tender services company to assist in the green procurement drive and phase seven will be the auditing of the registration process (NMBM 2011). 
Table 5 State of green procurement in local government as at 2013

\begin{tabular}{|c|c|}
\hline 2014 Current State & Local government \\
\hline Green public procurement guidelines/strategy developed & $\begin{array}{l}\text { Nelson Mandela Bay } \\
\text { Metropolitan } \\
\text { City of Cape Town }\end{array}$ \\
\hline $\begin{array}{l}\text { Procurement/supply chain management policy with green procurement } \\
\text { incorporated }\end{array}$ & $\begin{array}{l}\text { City of Cape Town } \\
\text { eThekwini }\end{array}$ \\
\hline Environmental polices related to or influencing green procurement & $\begin{array}{l}\text { City of Tshwane } \\
\text { Ekurhuleni Metro } \\
\text { Nelson Mandela Bay } \\
\text { Metropolitan }\end{array}$ \\
\hline Waste management Policy related to or influencing green procurement & $\begin{array}{l}\text { City of Cape Town } \\
\text { City of Johannesburg }\end{array}$ \\
\hline $\begin{array}{l}\text { Energy and climate change policy related to or influencing green } \\
\text { procurement }\end{array}$ & Ekurhuleni \\
\hline A stand-alone environmental policy & $\begin{array}{l}\text { City of Cape Town } \\
\text { City of Johannesburg } \\
\text { City of Tshwane } \\
\text { Ekurhuleni Metropolitan } \\
\text { eThekwini Metropolitan } \\
\text { Nelson Mandela Bay } \\
\text { Metropolitan }\end{array}$ \\
\hline A stand-alone procurement/supply chain policy & $\begin{array}{l}\text { Buffalo City Metropolitan } \\
\text { City of Cape Town } \\
\text { City of Johannesburg } \\
\text { City of Tshwane } \\
\text { Ekurhuleni Metropolitan } \\
\text { eThekwini Metropolitan } \\
\text { Mangaung Metropolitan } \\
\text { Nelson Mandela Bay } \\
\text { Metropolitan }\end{array}$ \\
\hline No environmental policy and no environmental initiatives related to GPP & $\begin{array}{l}\text { Buffalo City Metropolitan } \\
\text { Mangaung Metropolitan }\end{array}$ \\
\hline
\end{tabular}

Source Fieldwork (2013) Modified after IISD (2008) and SEED (2012)

In analysing policies and documents, the study found out that metropolitans made reference to green procurement in different policies. As indicated in Table 5. This is a follow-up on the 2008 studies by IISD and the 2012 study by Urban SEED (see section 2.6).

Table 5 indicates that City of Cape Town and City of Johannesburg make reference to green procurement in their integrated waste management policies of 2006 and 2011, respectively. City of Tshwane and Ekurhuleni make reference to green procurement in their environmental policies. Ekurhuleni also make reference to green procurement in its 2007 energy and climate change strategy. City of Cape Town and eThekwini make reference to green procurement in their 2013 SCM policies. In view of this, it was observed that all the metropolitans are striving to fulfil their climate change mitigation mandates by 
engaging in different projects to reduce their GHG emissions. In pursuit of engaging in the 'green projects', green procurement is practiced.

\section{Conclusion}

It emerged that although all the eight metropolitan municipalities have procurement policies in place, only the City of Cape Town and eThekwini metropolitan have incorporated green procurement strategies into their supply chain management. The City of Cape Town and Nelson Mandela Bay metropolitan municipalities also emerged as the only ones with stand-alone green procurement strategies. It was also established through document analysis that the linkage between mitigation and green procurement still needs to be strengthened in the policies. The research further concludes that legislative provisions mandating green procurement in South African metropolitan municipalities are not entirely lacking.

The lack of implementation of green procurement in the metropolitans can therefore be attributed to the lack of adequate policy frameworks. In spite of this, the study found out that all the metropolitans are undertaking mitigation projects to reduce greenhouse gas emissions. Projects in the transport sector such as the bus rapid transport, in the waste sector such as recycling and methane capture from landfills and in the energy sector such as installation of solar energy were identified. All the identified projects are, however, fragmented. These projects were found to be in different departments with limited coordination between departments and at times within the same department. This sometimes lead to duplication and in such instances, resources are wasted.

The study recommends that more work needs to be done to roll out and mainstream specific green procurement legislation to all the eight existing metropolitan municipalities. In addition, if green procurement is to take residence in South African metropolitan municipalities, education, awareness, training and capacity development should be extended to procurement and other decision making officials from these municipalities.

Open Access This article is distributed under the terms of the Creative Commons Attribution 4.0 International License (http://creativecommons.org/licenses/by/4.0/), which permits unrestricted use, distribution, and reproduction in any medium, provided you give appropriate credit to the original author(s) and the source, provide a link to the Creative Commons license, and indicate if changes were made.

\section{References}

Adewumi, E., \& Allopi, D. (2014). Critical assessment of Port Elizabeth bus rapid Transit system. Journal of Architecture and Civil Engineering, 2(1), 1-09.

Bailey, K. D. (1994). Methods of Social Research (4th ed.). New York: Free Press.

Bolton, P. (2008). Protecting the environment through public procurement: The case of South Africa. Natural Resources Forum, 32(1), 1-10.

Brammer, S., \& Walker, H. (2011). Sustainable procurement in the public sector: An international comparative study. International Journal of Operations \& Production Management, 31(4), 452-476.

City of Cape Town. (2003). Integrated municipality environmental policy. Cape Town Metropolitan Municipality.

City of Cape Town. (2006). Integrated waste management policy. Cape Town Metropolitan Municipality.

City of Cape Town. (2012). Information and guideline document on the implementation of green public procurement in the City of Cape Town. Cape Town Metropolitan Municipality.

City of Toronto. (2012). Trash to cash-methane capture generates \$3-4 million annually. http://www.c40. org/case_studies/. Accessed 22 July 2014. 
City of Tshwane. (2005). Tshwane integrated environmental policy (TIEP). Pretoria: City of Tshwane Metropolitan Municipality.

City of Tshwane. (2007). The TIEP implementation plan. City of Tshwane Metropolitan Municipality: Pretoria.

Correia, F., Howard, M., Hawkins, B., Pye, A., \& Lamming, R. (2013). Journal of Purchasing \& Supply Management, 19, 58-64.

Crespin-Mazet, F., \& Dontenwill, E. (2012). Sustainable procurement: Building legitimacy in the supply network. Journal of Purchasing \& Supply Management, 18, 207-217.

Creswell, J. W. (2003). Research design: Qualitative, quantitative and mixed methods approaches. Thousand Oaks, CA: Sage.

Department of Environmental Affairs-DEA. (2011). South Africa National climate change response white paper. Pretoria: Government Printers.

Ekurhuleni. (2006). Environmental policy. Ekurhuleni Metropolitan Municipality.

Ekurhuleni. (2012). Ekurhuleni metropolitan municipality: Solar PV installation. Ekurhuleni Metropolitan Municipality.

Ekurhuleni. (2013). Environmental policy and implementation plan. Ekurhuleni Metropolitan Municipality.

eThekwini. (2002). eThekwini environmental policy (construction). eThekwini Metropolitan Municipality.

eThekwini. (2005). Environmental management policy for the eThekwini Municipality. eThekwini Metropolitan Municipality.

eThekwini. (2013). eThekwini municipality: Supply chain management policy. eThekwini Metropolitan Municipality.

Harrison, P. A., Berry, P. M., \& Paterson, J. S. (2010). Climate change adaptation and mitigation: Synergies, antagonisms and trade-offs for biodiversity and ecosystems services. BOU conference proceedingsclimate changeand birds. http://www.bou.org.uk/bouproc-net/ccb/harrison-etal.pdf. Accessed 4 Apr 2014.

ICLEI (International Council for Local Environmental Initiatives). (2000). Green purchasing: Good practice guide. An ICLEI policy and practice publication. London: ICLEI.

International Institute for Sustainable Development-IISD. (2008). Sustainable public procurement in South Africa. www.iisd.org. Accessed 14 Oct 2013.

Klein, R. J. T., Schipper, E. L. F., \& Dessai, S. (2005). Integrating mitigation and adaptation into climate and development policy: Three research questions. Environmental Science \& Policy, 8(6), 579-588.

Mexico City. (2011). Mexico City replaced 3,000 Taxis with more fuel efficient models. http://www.c40. org/case_studies/. Accessed 22 July 2014.

Nelson Mandela Bay. (2011). Green procurement implementation strategy. Nelson Mandela Bay Metropolitan Municipality.

Nelson Mandela Bay Metropolitan Municipality. (2012). Integrated environmental policy for the Nelson Mandela Bay Metropolitan Municipality.

Nelson Mandela Bay Metropolitan Municipality. (2013). Supply chain management policy. Version 4.Nelson Mandela Bay Municipality.

OECD (Organisation of Economic Co-operation and Development). (2007). Giving knowledge for free: The emergence of open educational resources. http://www.oecd.org/edu/ceri/38654317.pdf. Accessed 12 Sept 2016.

Rio de Janeiro. (2012). Gramacho landfill to gas energy system. The joint U.S.-Brazil initiative on urban sustainability, part of the U.S. Environmental Protection Agency. http://www.c40.org/case_studies/. Accessed 22 July 14.

RSA. (1998). Local government municipal demarcation act 27 of 1998. Pretoria: Government Printer.

RSA. (1999). Public finance management (PFMA) Act, no. 1 of 1999. Pretoria: Government Printer.

RSA. (2000). Preferential procurement policy framework (PPPFA) Act, no. 5 of 2000. Pretoria: Government Printer.

RSA. (2009). National climate change response policy. A discussion document for the National climate change response policy development summit.

RSA (Republic of South Africa). (1996). The Constitution of the Republic of South Africa, 1996. Cape Town: Government Printer.

Stigson, B., \& Russell, T. (1998). Greener purchasing: Opportunities and innovations. London: Greenleaf Publishing.

Testa, F., Grappio, P., Gusmerotti, N. M., Iraldo, F., \& Frey, M. (2016). Examining green public procurement using content analysis: Existing difficulties for procurers and useful recommendations. Environment, Development and Sustainability, 18, 197-219.

Testa, F., Iraldo, F., Frey, M., \& Daddi, T. (2012). What factors influence the uptake of GPP (green public procurement) practices? New evidence from an Italian survey. Ecological Economics, 82, 88-96. 
Touboulic, A., \& Walker, H. (2015). Theories in sustainable supply chain management: A structured literature review. International Journal of Physical Distribution \& Logistics Management, 45(1/2), 16-42.

Turley, L., \& Perera, O. (2014). Implementing sustainable public procurement in South Africa: Where to start. Manitoba: International Institute for Sustainable Development.

UK Department of Environment. Food and Rural Affairs (DEFRA). (2006). Procuring for the future: Sustainable procurement action plan. Recommendations from the sustainable procurement task force. https://www.gov.uk/government/uploads/system/uploads/attachment_data/file/69417/pb11710procuring-the-future-060607.pdf. Accessed 20 May 2014.

UNDESA (United Nations Department of Economic and Social Affairs). (2013). World economic and social survey: Sustainable development challenges. New York: UNDESA Secretariat.

Urban Sustainable Energy for Environment and Development. (2012). Green procurement: A guide for local government. Urban SEED update 2(10). http://www.cityenergy.org.za/uploads/resource_159.pdf. Accessed 20 Mar 2015.

Walker, H., \& Brammer, S. (2009). Sustainable procurement in the United Kingdom public sector. Supply Chain Management: An International Journal, 14(2), 128-137.

WCED (World Commission on Environmental and Development). (1987). Our common future: A Global agenda for change. Oxford: Oxford University Press.

World Summit on Sustaianable Development-WSSD. (2002). Johannesburg summit. 26 August-4 September, 2002, Johannesburg, South Africa. 